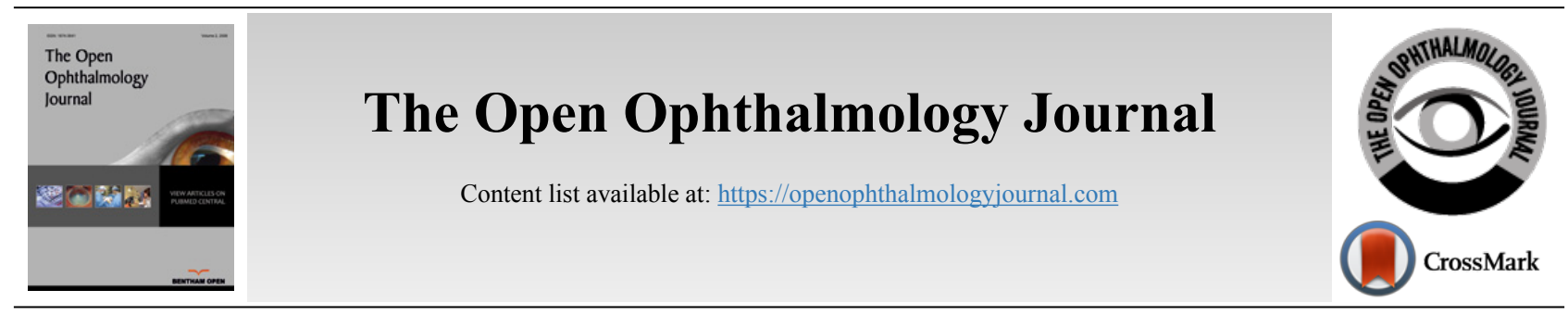

SYSTEMATIC REVIEW

\title{
Prevalence of Refractive Errors among Children in Saudi Arabia: A Systemic
} Review

\author{
Waleed Alghamdi ${ }^{1,2, *}$ \\ ${ }^{\prime}$ Department of Optometry, College of Applied Medical Science, Qassim University, Qassim, Saudi Arabia \\ ${ }^{2}$ School of Optometry \& Vision Science, University of New South Wales, Sydney, Australia
}

\begin{abstract}
:
Introduction:

The aim of this review was to estimate the prevalence of refractive errors (RE) and uncorrected refractive error (URE) in school-aged children of 4 to 14 years of age in Saudi Arabia.

Methods:

An extensive search was performed for peer-reviewed studies with data from the Saudi population during the past 20 years. The Cochrane Library, Pubmed, and Embase databases were used. Two independent reviewers evaluated publications and extracted the data. The quality of the studies was evaluated based on a critical appraisal tool designed for systematic reviews. The pooled prevalence of refractive error, uncorrected refractive error and different types of refractive error were estimated by using the random-effects meta-analysis.

\section{Results and Discussion:}

Eight school-based studies were included in this review. Among the overall pooled population of $12,247 \mathrm{childern}$, the estimated prevalence of refractive error was $17.5 \%(95 \%$ CI: 11.1- 25). In the five studies that reported uncorrected refractive error $(\mathrm{N}=10,198)$, the pooled prevalence was $16.8 \%$ (95\% CI: $11.4-21.3)$. The overall prevalence of refractive errors was very similar among boys, 16.8 (95\% CI: $10.8-24.1)$, and girls, $17.7 \%$ ( $95 \%$ CI: 10.2 - 25.9). Myopia was the most prevalent refractive error and was present in $40.8 \%$ (95\% CI: 16.1 - 69.9) followed by astigmatism $29.7 \%$ (95\% CI: 6.1- 61.7) and hyperopia $28.3 \%$ (95\% CI: $16.9-41.2)$.

\section{Conclusion:}

This review highlights the high prevalence of refractive errors and uncorrected refractive error among children in Saudi Arabia. More studies are required using standardised methods in different regions where there is a lack of information on UREs. It is recommended that vision screening programs of children for RE should be implemented at the community level and integrated into school health programmes in order to detect UREs and prevent amblyopia, which is one of the debilitating consequences of URE.
\end{abstract}

Keywords: Amblyopia, Hyperopia, Myopia, Refractive Errors, Visual Impairment, URE.

\begin{tabular}{|l|l|l|l} 
Article History & Received: October 26, 2020 & Revised: January 9, 2021 & Accepted: February 4, 2021
\end{tabular}

\section{INTRODUCTION}

Refractive Error (RE) is a major public health problem that affects a large proportion of children [1 - 3]. The World Health Organization (WHO) identified uncorrected RE (URE) as the leading cause of vision impairment globally [1]. Recent data estimate that about $90 \%$ of people with URE are living in rural and low-income countries [4]. However, other reports sugge-

\footnotetext{
* Address correspondence to this author at Department of Optometry, The College of Applied Medical Sciences, Qassim University, Qassim, Saudi Arabia; Tel: +966 50322 9636; E-mail: walghamdi@qu.edu.sa
}

sted that URE could still affect a large number of children in some high-income countries, despite the availability, affordability and accessibility to eye care services [5 - 7].

Studies have found that both hereditary and environmental factors play essential roles in the development and progression of $\operatorname{RE}[8,9]$. Because early visual defects are usually asymptomatic, uncorrected $\mathrm{RE}$ can negatively affect the learning capability of schoolchildren as well as their social and mental development $[3,10]$. Furthermore, because the visual system in children is still developing, impaired vision due to URE could affect the normal visual development and may 
result in amblyopia - a potentially irreversible visual impairment. Vision screening is recommended for pre-school children for early detection and treatment URE to ensure normal social and mental development and prevent amblyopia.

In 2016, more than 6.1 million $(30 \%)$ of the Saudi population were estimated to be below the age of 14 years [11]. However, a limited number of studies have investigated the prevalence of RE and URE in children in Saudi Arabia, and their results have been variable [6, 12 - 19]. For example, the RE can affect from $4.5 \%$ to up to $35.4 \%$ of children, while 4.3 to $34.9 \%$ has been assumed to be uncorrected [6,12 - 18]. which highlights the need to estimate the prevalence of RE and URE in this very young population. Ideally, national population-based studies are required to investigate the prevalence and risk factors of RE and URE in different regions of the country. Until then, a meta-analysis can be useful for estimating the pooled prevalence of RE and URE among children in Saudi Arabia. The data from such meta-analysis could provide needed data for planning of eye care programs for children in the country. Therefore, the main aim of this review is to estimate the prevalence of refractive errors among school-aged children of 4 to 14 years of age in Saudi Arabia.

\section{METHODS}

This systematic review followed the 2009 guidelines of the Preferred Reporting Items for Systematic Reviews and MetaAnalyses (PRISMA). Major databases were searched, including Cochrane Library, Pubmed, OVIS and EMbase databases. An extensive search strategy was used in this review which includes: (1) terms related to epidemiology by using words such as prevalence, epidemiology, incidence, rates and proportions, (2) terms related to conditions which included refractive error, myopia, hyperopia, astigmatism, and (3) terms related to population which included keyword search using the word Saudi or Saudi Arabia.

The methodological quality of the eligible studies was assessed using the 10- item checklist developed by Munn et al. [20] for prevalence studies. The following details were extracted from each study: study design, study population, refraction methods, location, number of subjects with refractive error, uncorrected refractive error, and number of children with different types of refractive error.

In this review, data from Saudi Arabia published between 1 January 2000 and 1 October 2020 were included. Other inclusion criteria were any quantitative study that reported the prevalence of any refractive errors from a Saudi population. Then, only data related to children between 4 and 14 years were then selected. Two independent reviewers performed the following review process: (A) searching and selecting studies; (B) critical review and methodological assessment of the studies;[REMOVED HYPERLINK FIELD] (C) Extraction of relevant data; and the author then performed statistical analysis and interpretation.

\subsection{Statistical Analysis}

MedCalc Statistical Software version 16.4.3 (MedCalc) was used to calculate the pooled estimate of refractive errors and uncorrected refractive errors in children. MedCalc uses the Freeman-Tukey double arcsine transformation with a randomeffects model. Additionally, the pooled prevalence of refractive errors by gender and types among children and for gender and types were performed. Chi-square-based Q test was used to assess the heterogeneity of reported prevalence among studies, while publication bias was assessed through funnel plots.

\section{RESULTS}

In this review, out of the 182 studies that investigated the ocular health in Saudi Arabia that were retrieved using the search criteria, only eight studies were found to fit the inclusion criteria i.e. included children younger than 14 years and conducted after the year 2000. The review strategy is summarized in Fig. (1), and the characteristics of all included studies are summarized in Table $\mathbf{1}$.

\section{Table 1. Characteristics of studies included in this review.}

\begin{tabular}{|c|c|c|c|c|c|c|c|c|c|c|c|c|c|c|}
\hline \multirow{2}{*}{$\begin{array}{c}\text { Study and } \\
\text { Year of } \\
\text { Publication }\end{array}$} & \multirow{2}{*}{$\begin{array}{c}\text { Year of } \\
\text { Data } \\
\text { Collection }\end{array}$} & \multirow[b]{2}{*}{ Design } & \multirow[b]{2}{*}{$\mathbf{N}$} & \multirow{2}{*}{$\begin{array}{c}\text { Age } \\
(\text { mean } \\
\pm \text { SD) }\end{array}$} & \multirow[b]{2}{*}{$\begin{array}{c}\text { Location } \\
\text { (region) }\end{array}$} & \multirow{2}{*}{$\begin{array}{c}\text { Refractive } \\
\text { Error } \\
\text { Definition }\end{array}$} & \multirow[b]{2}{*}{ Cycloplegic } & \multicolumn{3}{|c|}{ RE $\mathbf{n}$} & \multirow{2}{*}{$\begin{array}{c}\text { Uncorrected } \\
\text { RE }(N)\end{array}$} & \multicolumn{3}{|c|}{ RE Types n(\%) } \\
\hline & & & & & & & & $\begin{array}{c}\text { Total } \\
\text { RE }\end{array}$ & $\mathbf{M}$ & $\mathbf{F}$ & & Myopia & Hyperope & Astigmatism \\
\hline \multirow[t]{2}{*}{$\begin{array}{c}\text { Al-Rowaily. } \\
2010\end{array}$} & \multirow[t]{2}{*}{$\begin{array}{l}\text { March to } \\
\text { Oct } 2008\end{array}$} & $\begin{array}{c}\text { Cross-sectional School- } \\
\text { based }\end{array}$ & \multirow[t]{2}{*}{1319} & \multirow{2}{*}{$\begin{array}{c}* \text { Age } \\
\text { range } \\
4-8 \\
\text { years }\end{array}$} & \multirow[t]{2}{*}{$\begin{array}{l}\text { Riyadh } \\
\text { Central }\end{array}$} & \multirow{2}{*}{\begin{tabular}{|c|} 
Myopia: \\
$\leq-0.50 \mathrm{SE}$ \\
(D) \\
hyperopia: \\
$\geq 2.0 \mathrm{SE}$ (D) \\
\end{tabular}} & \multirow[t]{2}{*}{$\begin{array}{l}\text { No (Non- } \\
\text { cycloplegic } \\
\text { retinoscopy) }\end{array}$} & \multirow[t]{2}{*}{60} & \multirow[t]{2}{*}{24} & \multirow[t]{2}{*}{36} & \multirow[t]{2}{*}{ - } & \multirow[t]{2}{*}{25} & \multirow[t]{2}{*}{23} & \multirow[t]{2}{*}{33} \\
\hline & & & & & & & & & & & & & & \\
\hline $\begin{array}{l}\text { Aldebasi. } \\
2013\end{array}$ & $\begin{array}{l}\text { Sep } 2010- \\
\text { May } 2011\end{array}$ & Population school-based & 5176 & $\begin{array}{c}9.5 \pm \\
1.8\end{array}$ & $\begin{array}{l}\text { Qassim } \\
\text { Central }\end{array}$ & $\begin{array}{c}\text { Myopia: } \\
\leq-0.50 \mathrm{SE} \\
\text { (D) } \\
\text { hyperopia: } \\
\geq 2.0 \mathrm{SE} \text { (D) } \\
\text { Astigmatism: } \\
<-0.75 \mathrm{Dc} \\
\end{array}$ & Yes & 963 & 400 & 446 & 846 & 580 & 177 & 89 \\
\hline $\begin{array}{l}\text { Al Wadaani } \\
\text { et al. } 2011\end{array}$ & 2011 & Cross-sectional & 2246 & $\begin{array}{c}9.4 \\
\pm 2.3 y\end{array}$ & $\begin{array}{c}\text { Alehssa } \\
\text { (Eastern) }\end{array}$ & $\begin{array}{c}\text { Myopia: } \\
\leq-0.75 \mathrm{SE} \\
\text { (D) } \\
\text { hyperopia: } \\
\geq 2.0 \mathrm{SE} \text { (D) } \\
\text { Astigmatism: } \\
<-1.0 \mathrm{Dc}\end{array}$ & Yes & 274 & 113 & 161 & 253 & 214 & 60 & - \\
\hline
\end{tabular}




\begin{tabular}{|c|c|c|c|c|c|c|c|c|c|c|c|c|c|c|}
\hline \multirow{2}{*}{$\begin{array}{c}\text { Study and } \\
\text { Year of } \\
\text { Publication }\end{array}$} & \multirow{2}{*}{$\begin{array}{c}\text { Year of } \\
\text { Data } \\
\text { Collection }\end{array}$} & \multirow[b]{2}{*}{ Design } & \multirow[b]{2}{*}{$\mathbf{N}$} & \multirow{2}{*}{$\begin{array}{c}\text { Age } \\
(\text { mean } \\
\pm \text { SD) }\end{array}$} & \multirow{2}{*}{$\begin{array}{c}\text { Location } \\
\text { (region) }\end{array}$} & \multirow{2}{*}{$\begin{array}{l}\text { Refractive } \\
\text { Error } \\
\text { Definition }\end{array}$} & \multirow[b]{2}{*}{ Cycloplegic } & \multicolumn{3}{|c|}{ RE $n$} & \multirow{2}{*}{$\begin{array}{c}\text { Uncorrected } \\
\mathbf{R E}(\mathrm{N})\end{array}$} & \multicolumn{3}{|c|}{ RE Types n(\%) } \\
\hline & & & & & & & & $\begin{array}{c}\text { Total } \\
\text { RE }\end{array}$ & $\mathbf{M}$ & $\mathbf{F}$ & & Myopia & Hyperope & Astigmatism \\
\hline $\begin{array}{l}\text { Alrahili et } \\
\text { al. } 2017\end{array}$ & $\begin{array}{c}\text { April to } \\
\text { August } \\
2015 \\
\end{array}$ & Retrospective School-based & 1893 & $\begin{array}{c}9.4 \\
\pm 2.3\end{array}$ & $\begin{array}{c}\text { Madina } \\
(\text { Eastern })\end{array}$ & $\begin{array}{c}\text { AAPOS } \\
\text { guidelines } \\
{[13]}\end{array}$ & $\begin{array}{l}\text { No (auto } \\
\text { refractometer) }\end{array}$ & 681 & 332 & 329 & 661 & 26 & 29 & 467 \\
\hline $\begin{array}{c}\text { Alsaqr et al. } \\
2017\end{array}$ & $\begin{array}{c}\text { Jan- July } \\
2015\end{array}$ & $\begin{array}{c}\text { Cross-sectional School- } \\
\text { based }\end{array}$ & 335 & $\begin{array}{c}4.5 \pm \\
0.8\end{array}$ & $\begin{array}{l}\text { Riyadh } \\
\text { Central }\end{array}$ & \begin{tabular}{|c|} 
Myopia: \\
$\leq-0.50 \mathrm{SE}$ \\
(D)hyperopia: \\
$\geq 2.0 \mathrm{SE}$ (D) \\
Astigmatism: \\
$<-1.0 \mathrm{Dc}$ \\
\end{tabular} & $\begin{array}{l}\text { No (Non- } \\
\text { cycloplegic } \\
\text { retinoscopy) }\end{array}$ & 42 & 24 & 17 & 87 & 14 & 27 & - \\
\hline $\begin{array}{l}\text { Al Bahhawi } \\
\text { et al. } 2018\end{array}$ & Oct-15 & School-basedCross-sectional & 395 & $\begin{array}{c}* \text { Age } \\
\text { range } \\
6-14 \\
\text { years }\end{array}$ & $\begin{array}{l}\text { Jazan } \\
\text { (South) }\end{array}$ & \begin{tabular}{|c|} 
Myopia: \\
$\leq-0.75 \mathrm{SE}$ \\
(D) \\
hyperopia: \\
$\geq 1.0 \mathrm{SE}$ (D) \\
\end{tabular} & $\begin{array}{l}\text { No (Non- } \\
\text { cycloplegic } \\
\text { retinoscopy) }\end{array}$ & 87 & 87 & & - & 39 & 34 & 3 \\
\hline $\begin{array}{l}\text { Yaser Z, } \\
2019\end{array}$ & $\begin{array}{c}\text { January to } \\
\text { July } 2016\end{array}$ & $\begin{array}{c}\text { School-based Cross- } \\
\text { sectional }\end{array}$ & 414 & \begin{tabular}{|c|}
7.1 \\
\pm 0.8 \\
and \\
4.1 \\
\pm 0.8
\end{tabular} & $\begin{array}{l}\text { Riyadh } \\
\text { Central }\end{array}$ & \begin{tabular}{|c|} 
Myopia: \\
$\leq-0.50 \mathrm{SE}(\mathrm{D})$ \\
hyperopia: \\
$\geq 1.0 \mathrm{SE}(\mathrm{D})$ \\
Astigmatism: \\
$\quad<-2.0 \mathrm{Ds}$ \\
\end{tabular} & $\begin{array}{l}\text { No (spot } \\
\text { screener) }\end{array}$ & 94 & 31 & 64 & 77 & 46 & 13 & 39 \\
\hline $\begin{array}{l}\text { Alghamdi, } \\
2020\end{array}$ & $\mid \begin{array}{c}\text { Nov } 2019 \\
\text { to Jan } \\
2020\end{array}$ & $\begin{array}{l}\text { School-based Cross- } \\
\text { sectional }\end{array}$ & 417 & $\begin{array}{c}9.2 \pm \\
1.9\end{array}$ & $\begin{array}{l}\text { Uyoun } \\
\text { Aljawa } \\
\text { Central }\end{array}$ & \begin{tabular}{|c|} 
Myopia: \\
$\leq-0.50 \mathrm{SE}$ \\
(D) \\
hyperopia: \\
$\geq 2.0 \mathrm{SE}$ (D) \\
Astigmatism: \\
$<-1.0 \mathrm{Dc}$
\end{tabular} & $\begin{array}{l}\text { No (Non- } \\
\text { cycloplegic } \\
\text { retinoscopy }\end{array}$ & 82 & 82 & & 79 & 32 & 38 & 13 \\
\hline
\end{tabular}

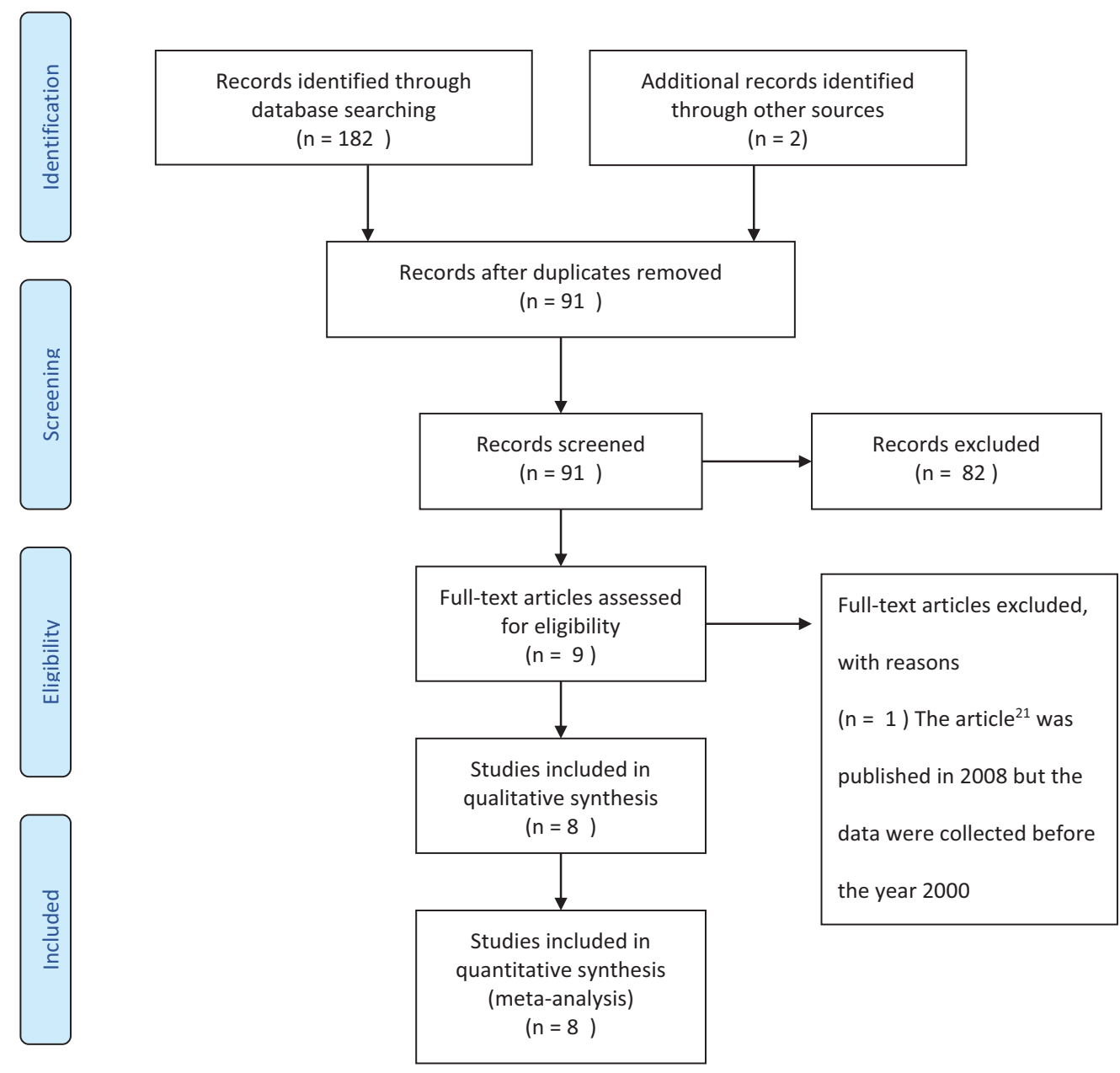

Fig. (1). Summary of review strategy - PRISMA Flow Diagram. 
All these studies were carried out by either optometrists or ophthalmologists and conducted between the year 2008 and 2019 in different regions of Saudi Arabia. The design of all included studies were cross-sectional, school-based studies but with significant differences in sample size, age group, refraction method used and the definition of refractive errors. The definition of uncorrected refractive error was similar across all studies reported it. The results of the quality assessment are summarized in Table 2. Significant high heterogeneity was found between the included studies reporting the prevalence of all refractive errors in children (Cochran's Q-test, $\mathrm{p}<0.001 ; \mathrm{I}^{2}=98$ percent). Although no evidence of publication bias was detected among the studies included in this review (Fig. 2), the small number of studies included in this meta-analysis $(\mathrm{n}=8)$ significantly undermines the reliability of the publication bias evaluation.

Among the overall pooled population of 12,247 children, the estimated prevalence of refractive error was $17.5 \%(95 \%$ CI: 11.1- 25). In the five studies that reported the URE $(\mathrm{N}=10198)$, the pooled prevalence was $16.8 \%$ (95\% CI: $11.4-$ 21.3). The overall prevalence of refractive error in boys $(\mathrm{N}=$ $6114)$ and girls $(\mathrm{N}=5563)$ were $16.8 \%$ (95\% CI: 10.8- 24.1) and $17.7 \%$ (95\% CI: $10.2-25.9)$, respectively. There was no significance difference in the prevalence of RE between boys and girls $(\mathrm{p}=0.1984)$. Myopia was the most prevalent refractive error $40.8 \%$ (95\% CI: 16.1 - 69.9) followed by astigmatism $29.7 \%$ (95\% CI: $6.1-61.7$ and hyperopia $28.3 \%$ (95\% CI: 16.9 - 41.2) (Fig. 2).

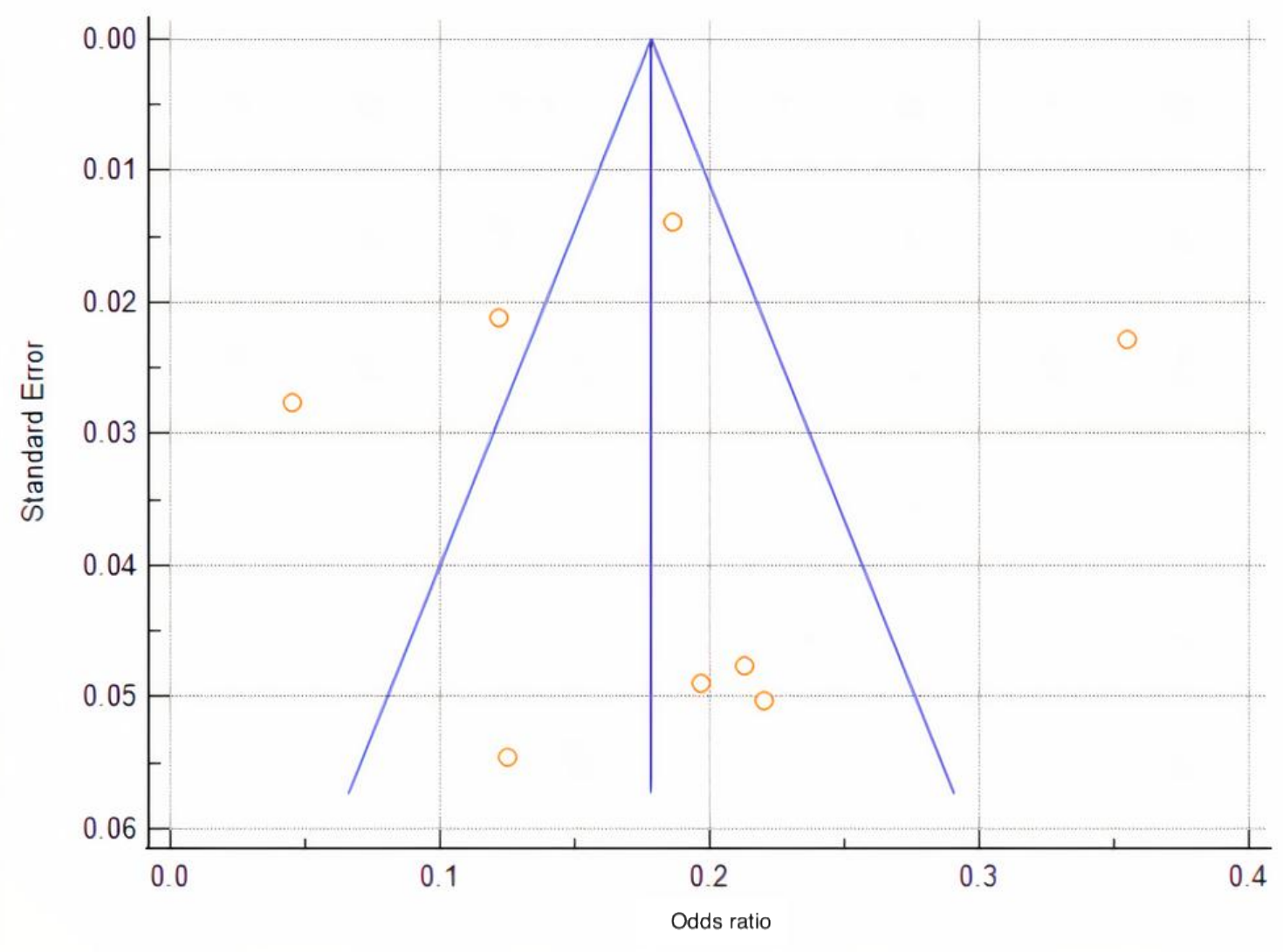

Fig. (2). Funnel plot showing the test for publication bias of prevalence of refractive error.

Table 2. Quality evaluation of the included study.

\begin{tabular}{|c|c|c|c|c|c|c|c|c|c|c|}
\hline Author & $\begin{array}{c}\text { Sample } \\
\text { representation } \\
\text { of the target } \\
\text { population? }\end{array}$ & $\begin{array}{c}\text { Appropriateness } \\
\text { of participants } \\
\text { recruitment }\end{array}$ & $\begin{array}{c}\text { Sample } \\
\text { size } \\
\text { adequacy }\end{array}$ & $\begin{array}{c}\text { Details of } \\
\text { study } \\
\text { subjects } \\
\text { and setting } \\
\text { description }\end{array}$ & \begin{tabular}{|c|} 
Data \\
analysis \\
with \\
sufficient \\
coverage \\
of the \\
identified \\
sample?
\end{tabular} & $\begin{array}{c}\text { Objective, } \\
\text { standard } \\
\text { criteria used } \\
\text { for } \\
\text { measurement } \\
\text { of the } \\
\text { condition? }\end{array}$ & $\begin{array}{c}\text { Condition } \\
\text { measured } \\
\text { reliably? }\end{array}$ & $\begin{array}{l}\text { Appropriate } \\
\text { statistical } \\
\text { analysis? }\end{array}$ & $\begin{array}{c}\text { All-important } \\
\text { confounding } \\
\text { factors/ } \\
\text { subgroups/ } \\
\text { differences } \\
\text { identified and } \\
\text { accounted } \\
\text { for? }\end{array}$ & \begin{tabular}{|c} 
Were \\
Subpopulations \\
Identified \\
using Objective \\
Criteria?
\end{tabular} \\
\hline $\begin{array}{c}\text { Al-Rowaily, } \\
2010\end{array}$ & $X$ & $\sqrt{ }$ & U & $\sqrt{ }$ & $\sqrt{ }$ & $\sqrt{ }$ & $\sqrt{ }$ & $\sqrt{ }$ & $\mathrm{X}$ & $\sqrt{ }$ \\
\hline
\end{tabular}




\begin{tabular}{|c|c|c|c|c|c|c|c|c|c|c|}
\hline Author & $\begin{array}{c}\text { Sample } \\
\text { representation } \\
\text { of the target } \\
\text { population? }\end{array}$ & $\begin{array}{c}\text { Appropriateness } \\
\text { of participants } \\
\text { recruitment }\end{array}$ & $\begin{array}{l}\text { Sample } \\
\text { size } \\
\text { adequacy }\end{array}$ & $\begin{array}{c}\text { Details of } \\
\text { study } \\
\text { subjects } \\
\text { and setting } \\
\text { description }\end{array}$ & \begin{tabular}{|c|} 
Data \\
analysis \\
with \\
sufficient \\
coverage \\
of the \\
identified \\
sample?
\end{tabular} & \begin{tabular}{|c|} 
Objective, \\
standard \\
criteria used \\
for \\
measurement \\
of the \\
condition?
\end{tabular} & $\begin{array}{c}\text { Condition } \\
\text { measured } \\
\text { reliably? }\end{array}$ & $\begin{array}{c}\text { Appropriate } \\
\text { statistical } \\
\text { analysis? }\end{array}$ & $\begin{array}{l}\text { All-important } \\
\text { confounding } \\
\text { factors/ } \\
\text { subgroups/ } \\
\text { differences } \\
\text { identified and } \\
\text { accounted } \\
\text { for? }\end{array}$ & \begin{tabular}{|c} 
\\
Were \\
Subpopulations \\
Identified \\
using Objective \\
Criteria?
\end{tabular} \\
\hline $\begin{array}{c}\text { Aldebasi. } \\
2013\end{array}$ & $\sqrt{ }$ & $\sqrt{ }$ & $\sqrt{ }$ & $\sqrt{ }$ & $\sqrt{ }$ & $\sqrt{ }$ & $\sqrt{ }$ & $\sqrt{ }$ & $\sqrt{ }$ & $\sqrt{ }$ \\
\hline $\begin{array}{c}\text { Al Wadaani } \\
\text { et al. } 2011\end{array}$ & $\sqrt{ }$ & $\sqrt{ }$ & $\sqrt{ }$ & $\sqrt{ }$ & $\sqrt{ }$ & $\sqrt{ }$ & $\sqrt{ }$ & $\sqrt{ }$ & $\sqrt{ }$ & $\sqrt{ }$ \\
\hline \begin{tabular}{|c|} 
Alrahili et \\
al. 2017
\end{tabular} & $\sqrt{ }$ & N/A & $\sqrt{ }$ & $\sqrt{ }$ & $\sqrt{ }$ & $\mathrm{U}$ & $\mathrm{U}$ & $\sqrt{ }$ & $\sqrt{ }$ & $\sqrt{ }$ \\
\hline $\begin{array}{c}\text { Alsaqr et al. } \\
2017\end{array}$ & $\sqrt{ }$ & $\sqrt{ }$ & $\mathrm{U}$ & $\sqrt{ }$ & $\sqrt{ }$ & $\sqrt{ }$ & $\mathrm{U}$ & $\sqrt{ }$ & $\sqrt{ }$ & $\sqrt{ }$ \\
\hline $\begin{array}{l}\text { AlBahhawi } \\
\text { et al. } 2018\end{array}$ & $\mathrm{U}$ & $\mathrm{U}$ & $\mathrm{U}$ & $\sqrt{ }$ & $\sqrt{ }$ & $\sqrt{ }$ & U & $\sqrt{ }$ & $\sqrt{ }$ & $\sqrt{ }$ \\
\hline $\begin{array}{c}\text { Yaser Z, } \\
2019\end{array}$ & $\mathrm{U}$ & $\sqrt{ }$ & $\mathrm{U}$ & $\sqrt{ }$ & $\sqrt{ }$ & $\mathrm{U}$ & $\sqrt{ }$ & $\sqrt{ }$ & $\sqrt{ }$ & $\sqrt{ }$ \\
\hline \begin{tabular}{|c|} 
Alghamdi, \\
2020
\end{tabular} & $\sqrt{ }$ & $\sqrt{ }$ & $\sqrt{ }$ & $\sqrt{ }$ & $\sqrt{ }$ & $\sqrt{ }$ & $\sqrt{ }$ & $\sqrt{ }$ & $\sqrt{ }$ & $\sqrt{ }$ \\
\hline
\end{tabular}

Table 3. Results of subgroup meta-analyses on the prevalence of refractive errors.

\begin{tabular}{|c|c|}
\hline Parameters & Overall Prevalence \\
\hline Refractive error & $17.5 \%$ (95\% CI: $11.1-25)$. \\
\hline Uncorrected Refractive error & $16.8 \%$ (95\% CI: $11.4-21.3)$ \\
\hline Refractive error by Gender & - \\
\hline Male & $16.9 \%$ (\% CI: $10.8-24.1)$ \\
\hline Female & $17.7 \%(95 \%$ CI: $10.2-25.9)$ \\
\hline Refractive error by type & - \\
\hline Myopia & $41.8 \%(95 \%$ CI: $16.1-69.9)$ \\
\hline Hyperopia & $28.3 \%(95 \%$ CI: $16.9-41.2)$ \\
\hline Astigmatism & $29.7 \%$ (95\% CI: $6.1-61.7)$ \\
\hline
\end{tabular}

\section{DISCUSSION}

This is the first systematic review on the prevalence of refractive errors among children in Saudi Arabia. This metaanalysis indicated a high burden of refractive errors in Saudi children affecting nearly 1 in every 5 children, and both females and males appear to be equally affected (Table $\mathbf{3}$ ). Despite the free and accessible eye care services in Saudi Arabia, the overall prevalence of URE is $16.8 \%$, which is considerably high when compared to other countries such as India [21] (10.8\%) or Chile [7] (4\%). These results highlight the high demand for a new national prevention strategy to reduce the numbers of uncorrected $\mathrm{RE}$ in the country effectively.

In addition, the overall prevalence of RE types reveals that myopia is the most common refractive error (41.8\%) among Saudi children, followed by astigmatism and hyperopia. It is unclear if this high percentage of myopia can be linked to the current global myopia epidemic, as no historical data are available to which these results can be compared. However, two recent studies $[22,23]$ indicated only about $25 \%$ of adult with RE were myopes, that is $12 \%$ less than what is reported in children in this review. This might suggest that myopia prevalence is on the rise among the younger generation in Saudi Arabia. Future studies are needed to confirm the prevalence, risk factors and pathogenesis of myopia and high myopia in the Saudi population.

There might be several reasons behind the high prevalence of uncorrected RE and other visual disorders among schoolchildren in Saudi Arabia. First and most important is the lack of efficient national vision screening programs for children in Saudi Arabia. While the vision examination is part of pre-school requirements, this role seems not to be strictly implemented, as the majority of children commence their schools without being examined by optometrists or ophthalmologists [24]. Secondly, several reports revealed that the general public in Saudi Arabia showed low levels of awareness and knowledge of the RE and other visual problems $[25,26]$. Also, another study [27] found that the compliance rate of spectacle wear in primary school children was only $33.4 \%$. Therefore, vision screening of children for RE should be conducted at the community level and integrated into school health programmes, accompanied by public awareness campaigns to guarantee that the corrections are used, and cultural barriers to compliance are addressed.

There are also other critical ocular findings from the included studies, which probably can be linked to the high numbers of UREs and the lack of vision screening programs for children in Saudi Arabia. For example, Aldebasi et al. [28] 
found that $3.9 \%$ of the primary school students in Qassim region had amblyopia while Alsaqr et al. [14] found 14\% of preschoolers in Riyadh were at risk of amblyopia. Alghamdi [18] found heterophoria in $12.5 \%$ of the primary school students in Uyoun Aljwa, a small central town of Saudi Arabia. Anisometropia was also reported to affect $3.7 \%$ to $7 \%$ of the children and as a primary risk factor of unilateral amblyopia in Saudi children [13, 15]. Furthermore, Alwadaani et al. [13] and Bahhawi et al. [16] found that children in rural areas were significantly more affected with RE than children in urban areas. It is noteworthy that no data were available from large and highly populated regions in Saudi Arabia, including Mekka, Assir, and Northern provinces in which each province have significant differences in demographic and socioeconomic conditions. Region-specific population-based studies are necessary to accurately characterize the epidemiology of ocular and vision abnormalities and to better understand the risk factors of RE and its relation to the quality of life.

The main limitation of this review was the limited number of published studies on the subject matter in Saudi Arabia, indicating limited data for adequate planning of refractive error services for school children. It is important to note there were only two studies $[6,13]$ met all the criteria suggested by Munn et al. (Table 2) and both of these studies were the only ones that used cycloplegic refraction, which is necessary to confirm the refractive error type for this age group. Also, there were clear differences in RE definitions, sample size, and only five studies reported the URE numbers while two studies included only male students. Nevertheless, all the studies showed adequate sample size calculation, proper statistical analysis, and their results interpretation seem appropriate. Thus, the outcomes of this meta-analysis are deemed appropriate and it is an important first step in understanding the magnitudes of RE and URE in Saudi Arabia.

\section{CONCLUSION}

In conclusion, this review highlights the high burden of refractive errors and uncorrected refractive errors among children in Saudi Arabia. More studies are required using standardized methods in different regions where there is a lack of information on UREs. Vision Screening programs of children for RE should be conducted at the community level and integrated into school health programmes.

\section{CONSENT FOR PUBLICATION}

Not applicable.

\section{STANDARDS OF REPORTING}

This systematic review followed the 2009 guidelines of the Preferred Reporting Items for Systematic Reviews and MetaAnalyses (PRISMA).

\section{FUNDING}

None.

\section{CONFLICT OF INTEREST}

The author declares no conflict of interest, financial or otherwise.

\section{ACKNOWLEDGEMENETS}

Declared none.

\section{REFERENCES}

[1] Resnikoff S, Pascolini D, Mariotti SP, Pokharel GP. Global magnitude of visual impairment caused by uncorrected refractive errors in 2004 . Bull World Health Organ 2008; 86(1): 63-70. [http://dx.doi.org/10.2471/BLT.07.041210] [PMID: 18235892]

[2] Schneider J, Leeder SR, Gopinath B, Wang JJ, Mitchell P. Frequency, course, and impact of correctable visual impairment (uncorrected refractive error). Surv Ophthalmol 2010; 55(6): 539-60. [http://dx.doi.org/10.1016/j.survophthal.2010.02.004] [PMID: 20850856]

[3] Dusek W, Pierscionek BK, McClelland JF. A survey of visual function in an Austrian population of school-age children with reading and writing difficulties. BMC Ophthalmol 2010; 10(1): 16. [http://dx.doi.org/10.1186/1471-2415-10-16] [PMID: 20500851]

[4] Naidoo KS, Jaggernath J. Uncorrected refractive errors. Indian J Ophthalmol 2012; 60(5): 432-7.

[http://dx.doi.org/10.4103/0301-4738.100543] [PMID: 22944755]

[5] Saw S-M, Goh P-P, Cheng A, Shankar A, Tan DT, Ellwein LB. Ethnicity-specific prevalences of refractive errors vary in Asian children in neighbouring Malaysia and Singapore. Br J Ophthalmol 2006; 90(10): 1230-5.

[http://dx.doi.org/10.1136/bjo.2006.093450] [PMID: 16809384]

[6] Aldebasi YH. Prevalence of correctable visual impairment in primary school children in Qassim Province, Saudi Arabia. J Optom 2014; 7(3): 168-76

[http://dx.doi.org/10.1016/j.optom.2014.02.001] [PMID: 25000873]

[7] Maul E, Barroso S, Munoz SR, Sperduto RD, Ellwein LB. Refractive error study in children: results from La Florida, Chile. Am J Ophthalmol 2000; 129(4): 445-54.

[http://dx.doi.org/10.1016/S0002-9394(99)00454-7] [PMID: 10764851]

[8] Wojciechowski R. Nature and nurture: the complex genetics of myopia and refractive error. Clin Genet 2011; 79(4): 301-20.

[http://dx.doi.org/10.1111/j.1399-0004.2010.01592.x] [PMID: 21155761]

[9] Goldschmidt E, Jacobsen N. Genetic and environmental effects on myopia development and progression. Eye (Lond) 2014; 28(2): 126-33.

[http://dx.doi.org/10.1038/eye.2013.254] [PMID: 24357837]

[10] Negrel AD, Maul E, Pokharel GP, Zhao J, Ellwein LB. Refractive Error Study in Children: Sampling and measurement methods for a multi-country survey. Am J Ophthalmol 2000; 129(4): 421-6. [http://dx.doi.org/10.1016/S0002-9394(99)00455-9] 10764848]

[11] Statistics GAf. Population characteristics surveys 2017.https://www.stats.gov.sa/en/854-0

[12] Al-Rowaily MA. Prevalence of refractive errors among pre-school children at King Abdulaziz Medical City, Riyadh, Saudi Arabia. Saudi J Ophthalmol 2010; 24(2): 45-8.

[http://dx.doi.org/10.1016/j.sjopt.2010.01.001] [PMID: 23960874]

[13] Al Wadaani FA, Amin TT, Ali A, Khan AR. Prevalence and pattern of refractive errors among primary school children in Al Hassa, Saudi Arabia. Glob J Health Sci 2012; 5(1): 125-34.

[http://dx.doi.org/10.5539/gjhs.v5n1p125] [PMID: 23283044]

[14] Alsaqr AM, Ibrahim G, Sharha AA, Fagehi R. Investigating the visual status of preschool children in Riyadh, Saudi Arabia. Middle East Afr J Ophthalmol 2017; 24(4): 190-4.

[http://dx.doi.org/10.4103/meajo.MEAJO 123 17] [PMID: 29422753]

[15] Alrahili NHR, Jadidy ES, Alahmadi BSH, et al. Prevalence of uncorrected refractive errors among children aged 3-10 years in western Saudi Arabia. Saudi Med J 2017; 38(8): 804-10.

[http://dx.doi.org/10.15537/smj.2017.8.20412] [PMID: 28762432]

[16] Al Bahhawi T, Makeen AM, Daghreeri HH, et al. Refractive error among male primary school students in Jazan, Saudi Arabia: Prevalence and associated factors. Open Ophthalmol J 2018; 12: 264-72.

[http://dx.doi.org/10.2174/1874364101812010264] [PMID: 30369991]

[17] Yasir ZH, Almadhi N, Tarabzouni S, Alhommadi A, Khandekar R. Refractive error of Saudi children enrolled in primary school and kindergarten measured with a spot screener. Oman J Ophthalmol 2019; 12(2): 114-8.

[http://dx.doi.org/10.4103/ojo.OJO_62_2017] [PMID: 31198298] 
[18] Alghamdi W. Errors and binocular anomalies in primary schools in uyoun aljawa: A small urban town in saudi arabia. Glob J Health Sci 2020; 12(10): 116-6.

[http://dx.doi.org/10.5539/gihs.v12n10p116]

[19] Bardisi W M, Bin Sadiq B M. Vision screening of preschool children in Jeddah, Saudi Arabia. Eye Care Review 2008; 2(1)

[20] Munn Z, Moola S, Riitano D, Lisy K. The development of a critical appraisal tool for use in systematic reviews addressing questions of prevalence. Int J Health Policy Manag 2014; 3(3): 123-8.

[http://dx.doi.org/10.15171/ijhpm.2014.71] [PMID: 25197676]

[21] Sheeladevi S, Seelam B, Nukella PB, Modi A, Ali R, Keay L. Prevalence of refractive errors in children in India: A systematic review. Clin Exp Optom 2018; 101(4): 495-503.

[http://dx.doi.org/10.1111/cxo.12689] [PMID: 29682791]

[22] Parrey MUR, Elmorsy E. Prevalence and pattern of refractive errors among Saudi adults. Pak J Med Sci 2019; 35(2): 394-8.

[http://dx.doi.org/10.12669/pjms.35.2.648] [PMID: 31086521]

[23] Almudhaiyan T, Alhamzah A, AlShareef M, et al. The prevalence of refractive errors among Saudi adults in Riyadh, Saudi Arabia. Saudi J Ophthalmol 2020; 34(1): 30-4. [http://dx.doi.org/10.4103/1319-4534.301297] [PMID: 33542984]

24] Aldebasi YH, Ahmed MI, Monaco WA. Are optometrists necessary in primary health care centres in Saudi Arabia? African Vision and Eye Health 2018; 77(1): 1-10.

[http://dx.doi.org/10.4102/aveh.v77i1.402]

[25] Aldebasi Y. Young public's awareness to refractive error deficiency. Int J Health Sci (Qassim) 2011; 5(1): 9-15. [PMID: 22489225]

[26] Al-Lahim WA, Al-Ghofaili RS, Mirghani H. ALBalawi, H., Evaluation of awareness and attitudes towards common eye diseases among the general population of Northwestern Saudi Arabia. Egyptian J Hosp Med 2018; 70(11): 1983-9. [http://dx.doi.org/10.12816/0044854]

[27] Aldebasi YH. A descriptive study on compliance of spectacle-wear in children of primary schools at Qassim Province, Saudi Arabia. Int J Health Sci (Qassim) 2013; 7(3): 291-9.

[http://dx.doi.org/10.12816/0006057] [PMID: 24533022]

[28] Aldebasi YH. Prevalence of amblyopia in primary school children in Qassim province, Kingdom of Saudi Arabia. Middle East Afr J Ophthalmol 2015; 22(1): 86-91.

[http://dx.doi.org/10.4103/0974-9233.148355] [PMID: 25624680]

\section{(C) 2021 Waleed Alghamdi}

This is an open access article distributed under the terms of the Creative Commons Attribution 4.0 International Public License (CC-BY 4.0), a copy of which is available at: https://creativecommons.org/licenses/by/4.0/legalcode. This license permits unrestricted use, distribution, and reproduction in any medium, provided the original author and source are credited. 